Research Article

\title{
Evaluation of the relation of Platelet Volume Index, MPV and RDW values with mortality in spontaneous intraparenchymal hemorrhages
}

Spontan intraparankimal kanamalarda Platelet Volüm İndex, MPV ve RDW değerlerinin mortalite ile ilişkisinin değerlendirilmesi

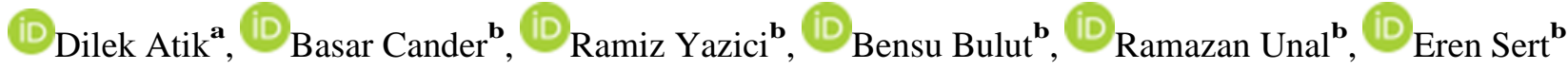 \\ ${ }^{\text {a }}$ Department of Emergency Medicine, Yozgat Bozok University, Yozgat, Turkey \\ ${ }^{\text {a }}$ Department of Emergency Medicine, University of Health Sciences Kanuni Sultan Suleyman Research and Training Hospital, Istanbul, Turkey
}

\begin{abstract}
Introduction: Intracerebral Spontaneous Hemorrhage (ISH) is a sudden hemorrhage into the brain parenchyma as a result of a rupture of the cerebral vessels that are not related to traumas. The purpose of the present study was to evaluate the relation of mortality with Platelet Volume Index (PVI) scoring systems, which have been reported in a small number of studies in terms of blood RDW, MPV, platelet and intracranial hemorrhages in patients diagnosed with intraparenchymal hemorrhage in Emergency Departments.

Methods: This study was performed retrospectively by examining patient files of patients who came to Emergency Medicine Clinic between 01.01.2019-31.12.2019. As a control group for comparison of blood parameters, blood parameters of 72 patients suitable for the same age population, without intraparenchymal haemorrhage.

Results: A total of $54.10 \%(n=85)$ intraparenchymal bleeding patients (IPC) and $45.90 \%(n=72)$ healthy control groups (HCG) were included in the study. There was no statistically significant difference between the clinical results of IPC groups in terms of mortality of RDW parameter and MPV parameter $(\mathrm{p}=0.930 ; \mathrm{p}=0.118)$. When PVI ratio was evaluated in IPC group and HCG; the mean PVI (MPV/Platelet ratio) in the IPC group

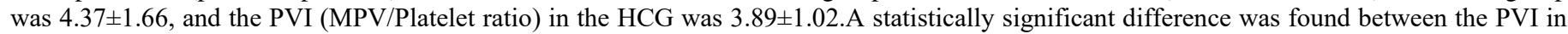
the patient group and the HCG.A statistically significant difference was found between the PVI ratio clinical results of the patients with IPC $(\mathrm{p}=0.043)$.

Conclusion: Spontaneous Intraparenchymal hemorrhage are among the leading causes of stroke-induced mortality and disability. The Hemphill Score and hemorrhage volume are important factors in mortality evaluation in intraparenchymal hemorrhage. There are not many studied conducted on Platelet Volume Index, and it is an important marker in predicting mortality, especially in these patients.

Keywords: Intraparenchymal haemorrhage, Mean platelet volume, Red cell distribution width
\end{abstract}

\section{$\ddot{O} \mathbf{z}$}

Giriş: Spontan İntraserebral hemoraji (İSH), aniden oluşan ,travmaya bağlı olmayan beyin damarları rüptürü sonucu beyin parankimi içine kanamalardır. Bu çalışma ile intraparankimal kanama tanısı alan hastalarında kan RDW, MPV, platelet ve şu ana kadar intrakraniyal hemorajilerde az sayıda çalışma bildirilen platelet volüm indexinin (PVI) skorlama sistemleri ile birlikte mortalite ilişkisini değerlendirmesini amaçladık.

Yöntem: Bu çalışma 01.01.2019-31.12.2019 tarihleri arasında Acil Tıp Kliniğine gelen hastaların hasta dosyaları incelenerek retrospektif olarak yapıldı. Kan parametrelerinin karşılaştııılması için kontrol grubu olarak, intraparankimal kanama olmayan aynı yaş popülasyonuna uygun 72 hastanın kan parametreleri değerlendirildi. Klinik sonuçlara göre RDW, MPV, Platelet ve PVI kan parametreleri değerlendirildi.

Bulgular: Çalışmaya toplam \%54,10 ( $\mathrm{n}=85)$ intraparankimal kanama hastası (IPK) ve \%45,90 $(\mathrm{n}=72)$ sağlıklı kontrol grubu (SKG) dahil edildi. IPK gruplarının klinik sonuçları arasında RDW parametresi ve MPV parametresinin mortalitesi açısından istatistiksel olarak anlamlı bir fark yoktu

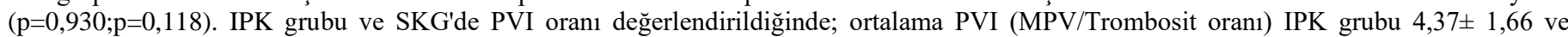
SKG'deki PVI (MPV/Trombosit oran1) 3,89 \pm 1,02 idi. Hasta grubundaki PVI oranı ile SKG arasında istatistiksel olarak anlamlı bir fark bulundu. IPC'li hastaların PVI oranı klinik sonuçları değerlendirildi; mortalite açısından gruplar arasında istatistiksel olarak anlamlı fark vardı $(\mathrm{p}=0,043)$. Sonuç: Spontan intraparankimal kanama, inmeye bağlı mortalite ve özürlülüğün önde gelen nedenleri arasındadır. Hemphill Score ve kanama hacmi intraparankimal kanamada mortalite değerlendirmesinde önemli faktörlerdir. Platelet Hacim İndeksi üzerine yapılmış çok fazla çalışma yoktur ve özellikle bu hastalarda mortaliteyi öngörmede önemli bir belirteçtir.

Anahtar Kelimeler: İntraparankimal kanama, Ortalama trombosit hacmi, Kırmızı hücre dağılım genişliği

\begin{tabular}{|c|c|c|c|c|}
\hline Received & Accepted & Published Online & Corresponding Author & E-mail \\
\hline October 27, 2020 & February 3, 2021 & April 3, 2021 & Dilek Atik, MD & dr.dilekgok82@ @otmail.com \\
\hline Correspondence & $\begin{array}{l}\text { Dr. Dilek Atik, Yozgat Bozok University, Menderes mh. Adnan Menderes Blv. Merkez, Yozgat, 66200, } \\
\text { Turkey }\end{array}$ \\
\hline
\end{tabular}




\section{Introduction}

Cerebrovascular diseases rank the third in terms of disability, in the second as the cause of mortality [1] and cerebrovascular diseases are basically classified into two groups as ischemic and hemorrhagic. Intracerebral Spontaneous Hemorrhage (ISH) is a sudden hemorrhage into the brain parenchyma as a result of a rupture of the cerebral vessels that are not related to traumas [2]. Intraparenchymal Hemorrhages are one of the diseases that have limited mortality, morbidity and treatment options [3]. Many parameters and scoring systems were reported to predict mortality in cerebrovascular diseases [4]. It was reported in some studies that the prognosis of intracerebral hemorrhage is determined by factors such as hematoma size, age, interventricular hemorrhage, and the activation of the inflammation process in intraparenchymal hemorrhages [6-8].

The RDW laboratory parameter, which is associated with inflammation in the light of the literature information, is called as the distribution width of the red blood cell [9]. RDW is the blood parameter that determines the mortality in many chronic diseases and vascular diseases regardless of hemoglobin and hematocrit [10-12]. It was reported in studies in the literature that there were increased RDW levels in the formation of clinically inflammatory conditions [9].

The platelet cells that were included in the scope of this study are responsible for cellular inflammation as well as chemokine, cytokine production and inflammatory process. Also, platelets play important roles in the migration of progenitor cells and leukocyte to vascular damage areas, and in the circulation of anti-inflammatory, proinflammatory, angiogenic factors and micro particles [13,14]. The Mean Platelet Volume (MPV), which is a marker of the functions of platelet cells, indicates platelet activation. In general, large platelets are considered to be more reactive [15,16]. It is reported in the literature that the MPV values increase in acute ischemic diseases and MPV values decrease in activation periods of chronic inflammatory diseases [17,18]. The change in the MPV value in acute and chronic diseases remains uncertain in terms of its association with mortality, especially in intracranial hemorrhage [19]. The PVI (Platelet Volume Index) plays roles specially to evaluate the activities of platelets that play roles in inflammation more clearly [20]. In some previous studies, it was reported that PVI is one of the thromboembolism markers and may be an important marker in evaluating the risk of cardiovascular disease in diabetes and hypertension [21, 22].

The purpose of the present study was to evaluate the relation of mortality with Platelet Volume Index (PVI) scoring systems, which have been reported in a small number of studies in terms of blood RDW, MPV, platelet and intracranial hemorrhages in patients diagnosed with intraparenchymal hemorrhage in Emergency Departments.

\section{Method}

\section{Study Design}

The present study was conducted retrospectively by examining the Hospital Automation System and patient files admitting to Yozgat Bozok University and Istanbul Health Sciences University Kanuni Sultan Suleyman Education and Research Hospital Emergency Medicine Clinic between 01.01.2019 and 31.12.2019 with intraparenchymal hemorrhage. Patients who were over the age of 18 were included in the study. The approval of the study was obtained from the Local Ethics Committee. In the records, 85 patients who had complete files among the total 105 patients were included in the study. As the Control Group to compare the blood parameters, the blood parameters of 72 patients of the same age group with nonspecific complaints and no additional diseases were evaluated. According to the clinical results of the patient data, they were divided into patients with healthy discharge and those who died. The 30-day mortality of the patients was evaluated. The Hemphill Score was used as the index in intraparenchymal hemorrhage. The Hemphill Score consists of the volume of hemorrhage, age, basal Glasgow Coma Scale (GKS) scores, and the presence of intraventricular and infratentorial hemorrhage [23].

Those with Glasgow Coma Scale 13-15 were included in Group 1, GKS 5-12 in Group 2, GKS 3-4 Group 3. In the first 24 hours of hospital admissions of the patients with intracerebral hemorrhage, full blood count values were recorded from venous blood samples placed in tubes with EDTA. In blood analysis, the MPV, RDW, Platelet (PLT) blood parameters were recorded from the files of each patient and for the control group. Platelet Volume Index was calculated as PVI = MPV value (fl)/PLT per $1000 \times 100$ [24], and the calculated PVI values were then recorded. The hemorrhage size of the patients with intraparenchymal hemorrhage was recorded. The elimination of the causes that might lead to similar clinical and imaging findings (i.e., hemorrhage into the intracranial mass or trauma-related intracranial hemorrhage, and hemorrhagic transformation into the ischemic area) was excluded from the study. The hemorrhage volume of the patients who were included in the study was calculated by using the ABC/2 Formula [17]. The volume of the hematoma mass was calculated in approximately milliliters (ml) as a result of multiplying the widest diameter in CT section. Intraparenchymal hematoma locations were classified according to residential areas as lobber, deep parenchymal, and infratentorial. There were two groups according to the way it was opened to the ventricle and not.

\section{Ethical approval}

The ethical approval was obtained from the Ethics Committee of Yozgat Bozok University (IRB Number: 2019-10-218, Date: 30.10.2019)

\section{Statistical Analysis}

SPSS statistical software (version 20.0; SPSS, Chicago, IL) was used to complete all analyses. Descriptive statistics were used in the demographic examination of the patients. In the study, the Chi-Square Test was applied if the data were qualitative. When the study data were evaluated, numerical values were expressed as mean \pm standard deviation. In the context of clinical research, the Mann-Whitney U-test were used in statistical evaluations according to the categorical (nominal or ordinal) and numerical independent groups of nonparametrically related variables. Spearman Rank Correlation Method was used in nonparametric data for correlations between data. According to the clinical results, the efficiency of RDW, MPV, PVI, and hemorrhage size was evaluated in terms of mortality with ROC curve (Receiver-Operating Characteristics Curve). The results were evaluated at a significance level of $\mathrm{p}<0.05$. 


\section{Results}

A total of $54.10 \%(n=85)$ patients with intraparenchymal hemorrhage (IPK) and $45.90 \%(n=72)$ healthy control group (HCG) between 01.01 .2019 -31.12.2019 were included in the study. In our study, data of 85 patients who were admitted to the hospital due to IPK (Intraparenchymal Hemorrhage) and with complete file data were analyzed. The results of the analysis are shown in Table 1 (Table 1). No significant differences were detected in median age between 85 patients with IPK and 72 control group ( $\mathrm{z}:-0.338 ; \mathrm{p}=0.735)$. A total of 34.10\% ( $\mathrm{n}=29)$ of the IPK patients were female, and $65.90 \%(\mathrm{n}=56)$ were male. The healthy control group consisted of $51.49 \%(\mathrm{n}=37)$ female, and $48.51 \%(\mathrm{n}=35)$ male individuals, and no significant differences were detected in terms of gender between the two groups $\left(\chi^{2}: 2.423 ; \mathrm{p}=0.120\right)$.

Table 1. The Demographic characteristics of the study groups

\begin{tabular}{|c|c|c|c|c|c|}
\hline $\begin{array}{c}\text { Demographic Characteristics - } \\
\text { Independent Variables (IVs) }\end{array}$ & Name of Characteristics & Number & $\begin{array}{l}\text { Percent } \\
(\%)\end{array}$ & Mean \pm SD & $\mathbf{p}$ \\
\hline \multirow{2}{*}{ Patients, Gender } & Female & 29 & 34.10 & & \\
\hline & Male & 56 & 65.90 & & \\
\hline \multirow[t]{2}{*}{ Control, Gender } & Female & 37 & 51.49 & & \\
\hline & Male & 35 & 48.51 & & \\
\hline \multicolumn{6}{|l|}{ Statistical Analysis (Chi-Square Test) } \\
\hline Patients, Age & & & & $60.09 \pm 15.06$ & \\
\hline Control, Age & & & & $60.27 \pm 10.35$ & $0.120^{*}$ \\
\hline \multicolumn{6}{|l|}{ Statistical Analysis (Mann-Whitney U-test) } \\
\hline \multirow[t]{2}{*}{ Clinical results of patients } & Discharged with Health & 66 & 77.64 & & $0.735^{*}$ \\
\hline & Exitus & 19 & 22.36 & & \\
\hline
\end{tabular}

Chi-Square Test item was used as statistical analysis.

Mann-Whitney U-test were used in statistical evaluations according to numerical independent groups of nonparametrically related variables. .* Not significant.

\section{Clinical findings of patients with intraparenchymal hemorrhage}

The clinical findings of the intraparenchymal patients and the hemorrhage characteristics parameters that made up the Hemphill Score are shown in Table 2. In this respect, when the Glasgow Coma Scale (GCS) scores of the patients were evaluated, patients had 68.20\% (n=58\%) GCS 13-15, $25.91 \%(\mathrm{n}=22)$ GCS 5-12, and GCS $<55.89 \%(\mathrm{n}=5)$. The mean hematoma volume of the patients was $12.26 \pm 13.37 \mathrm{cc}(\mathrm{min}: 0.18$; max: 60$)$. The hematoma locations of the patients were recorded as $45 \%$ (39) lobber, 35\% $(n=29)$ deep parenchymal, and 20\% ( $n=17)$ infratentorial. In the mortality evaluation according to hematoma regions, infratentorial hemorrhage had the highest mortality rates, and $47.1 \%$ of the patients died. There were statistically significant differences in mortality between the groups $(\mathrm{p}<0.05)$.

Table 2. Distribution of patients according to their clinical results

\begin{tabular}{|c|c|c|c|}
\hline Clinical final results & Discharged with Cure n(\%) & Died & P value \\
\hline $\begin{array}{ll} & \text { Total }\end{array}$ & $66(77.6)$ & $19(22.4)$ & \\
\hline \multicolumn{4}{|l|}{ Glasgow Coma Score } \\
\hline GCS 13-15 & $57(98.3)$ & $1(1.7)$ & \\
\hline GCS 5-12 & $9(40.9)$ & $13(59.1)$ & $<0.001^{\mathrm{a}}$ \\
\hline GCS $<5$ & - & $5(100)$ & \\
\hline \multicolumn{4}{|l|}{ Hematoma Location } \\
\hline Lobar & $37(94.9)$ & $2(5.1)$ & \\
\hline Deep parenchymal & $20(69)$ & $9(31)$ & $0.001^{\mathrm{a}}$ \\
\hline Infratentorial & $9(52.9)$ & $8(47.1)$ & \\
\hline
\end{tabular}

Chi-Square Test item was used as statistical analysis. a: Significant at the 0.05 level $(\mathrm{p}<0.05)$. GCS: Glasgow Coma Score

A total of $80 \%(n=68)$ hemorrhages were not opened to intraventricular area, and hematoma hemorrhages in 20\% (n=17) opened to intraventricular

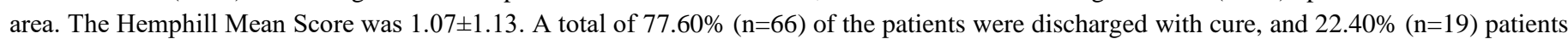
died. Hemphill Index Parameters are shown in Table 2. When the relation between the clinical final results of the patients was evaluated, GCS score was significantly lower in patients who died $(\mathrm{p}<0.05)$. However, mean hematoma volume and Hemphill Index mean were significantly higher in patients who died $(\mathrm{p}<0.05)$.

\section{Laboratory features of patient who had intraparenchymal hemorrhage and healthy control group}

The differences in the laboratory findings between the patients who had intraparenchymal hemorrhage and the control group are shown in Table 3. The RDW-CV level values were higher in the patient group than in the control group $(\mathrm{z} ;-3.036 ; \mathrm{p}=0.002)$. The PVI (MPV/Platelet) ratios were significantly higher in IPK patient group than healthy control group $(\mathrm{z}:-2.191 ; \mathrm{p}=0.028)$. Platelet laboratory parameter was significantly lower in the patient group than in the healthy group ( $\mathrm{z}:-3.239 ; \mathrm{p}=0.001)$. However, as seen in the table, the difference in the MPV laboratory parameter was not statistically significant in the patient and healthy group $(\mathrm{z}:-0.190 ; \mathrm{p}=0.985)$. 
Table 3. Laboratory characteristics of the patient with intraparenchymal hemorrhage and the healthy control group

\begin{tabular}{|c|c|c|c|}
\hline Blood Parameters & Groups & Mean \pm SD & $\mathbf{p}$ \\
\hline RDW Blood Parameter $(\%)$ & $\begin{array}{l}\text { Patients } \\
\text { Control }\end{array}$ & $\begin{array}{l}14.22 \pm 2.41 \\
13.23 \pm 1.33\end{array}$ & $0.002^{\mathrm{a}}$ \\
\hline MPV Blood Parameter(fL) & $\begin{array}{l}\text { Patients } \\
\text { Control }\end{array}$ & $\begin{array}{l}10.47 \pm 2.63 \\
10.11 \pm 0.95\end{array}$ & $0.985^{\mathrm{b}}$ \\
\hline Platelet Blood Parameter(u/L) & $\begin{array}{l}\text { Patients } \\
\text { Control }\end{array}$ & $\begin{array}{l}259.71 \pm 76.7 \times 10^{3} \\
288.69 \pm 96.6 \times 10^{3}\end{array}$ & $0.001^{\mathrm{a}}$ \\
\hline PVI (MPV/Platelet) Ratio & $\begin{array}{l}\text { Patients } \\
\text { Control }\end{array}$ & $\begin{array}{l}4.37 \pm 1.66 \\
3.89 \pm 1.02\end{array}$ & $0.028^{\mathrm{a}}$ \\
\hline
\end{tabular}

Mann-Whitney U-test item was used as statistical analysis. a: Significant at the 0.05 level $(\mathrm{p}<0.05)$, b: Not significant.

\section{Evaluation of laboratory parameters, clinical features and mortality relationship of intraparenchymal patient group}

The laboratory parameter evaluations according to the clinical results of the patients are shown in Table 4. In this respect, no significant differences were detected between the groups in the mortality assessment of patients with intraparenchymal hemorrhage of RDW-CV, MPV and platelet laboratory parameters (z:-0.878; $\mathrm{p}=0.930, \mathrm{z}:-1.563 ; \mathrm{p}=0.118, \mathrm{z}:-0.047 ; \mathrm{p}=0.962)$. However, the group of patients who died with PVI (MPV/PLT) had higher values in terms of clinical results and the PVI mean was significantly higher than the living patient group (z:-2.010; $\mathrm{p}=0.043)$. When the correlation between the Hemphill Index and PVI value was evaluated, a moderately positive and significant relation was detected ( $\mathrm{r}_{\mathrm{s}}: 0.423$; $\mathrm{p}=0.010$ ). The relation between intraparenchymal hematoma volume and laboratory parameters indirectly affects the Hemphill Index. When the hematoma volume parameter that is used in Hemphill Index calculation and RDW, MPV, Platelet and PVI relations were evaluated together, a positive and moderate relation was detected between PVI index and hematoma size; and a weak and negative relation was detected between platelet laboratory parameter $\left(\mathrm{r}_{\mathrm{s}}:-0.217 ; \mathrm{p}=0.046\right)$. However, no positive or negative $\mathrm{s}$ were detected in terms of the correlation of RDW and MPV blood parameters regarding hematoma size $(\mathrm{r}: \mathrm{s}: 0.182 ; \mathrm{p}=0.095, \mathrm{r}: 0.183 ; \mathrm{p}=0.094)$.

Table 4. Comparison of blood parameters according to the clinical course of the patients

\begin{tabular}{|c|c|c|c|}
\hline Blood Parameters & Groups & Mean $\pm S D$ & $p$ \\
\hline $\begin{array}{l}\text { RDW Blood } \\
\text { Parameter(\%) }\end{array}$ & $\begin{array}{r}\text { Healthy Discharge Patients With IPC } \\
\text { Ex Patients With IPC }\end{array}$ & $\begin{array}{l}14.34 \pm 2.51 \\
13.94 \pm 1.97\end{array}$ & $0.930^{\mathrm{b}}$ \\
\hline MPV Blood Parameter(fL) & $\begin{array}{r}\text { Healthy Discharge Patients With IPC } \\
\text { Ex Patients With IPC }\end{array}$ & $\begin{array}{l}10.04 \pm 1.07 \\
10.61 \pm 2.93\end{array}$ & $0.118^{b}$ \\
\hline $\begin{array}{l}\text { Platelet Blood } \\
\text { Parameter(u/L) }\end{array}$ & $\begin{array}{r}\text { Healthy Discharge Patients With IPC } \\
\text { Ex Patients With IPC }\end{array}$ & $\begin{array}{r}261.26 \pm 69.02 \\
\times 10^{3} \\
252.89 \pm 69 \times 10^{3}\end{array}$ & $0.962^{b}$ \\
\hline PVI (MPV/Platelet) Ratio & $\begin{array}{r}\text { Healthy Discharge Patients With IPC } \\
\text { Ex Patients With IPC }\end{array}$ & $\begin{array}{l}4.47 \pm 2.29 \\
5.37 \pm 1.70\end{array}$ & $0.043^{\mathrm{a}}$ \\
\hline
\end{tabular}

\section{ROC analysis for Hemphill Index, hematoma size, MPV/PLT parameters}

The Hemphill Index, PVI and hematoma size, which are statistically significant for using to predict the mortality of IPK patients, and the EAA, cut-off, sensitivity and specificity were analyzed with the ROC curve for distinguishing the diagnostic efficacy and patient follow-up to guide the clinician about the patient's condition. The AUC, cut-off, sensitivity, specificity of the PVI were $0.708,5.13,68.42 \%$ and $81 \%$, respectively for predicting mortality. The Hemphill Score, AUC, cut-off, sensitivity, and specificity were $0.9031 .54 \%, 84.83 \%$ and $78 \%$, respectively. The ROC analysis results of the Hematoma Size in predicting mortality, AUC, cut-off, sensitivity, and specificity were $0.80719 .51 \mathrm{cc}, 83.32 \%$ and $68 \%$, respectively (Figure 1). 


\section{ROC Curve}

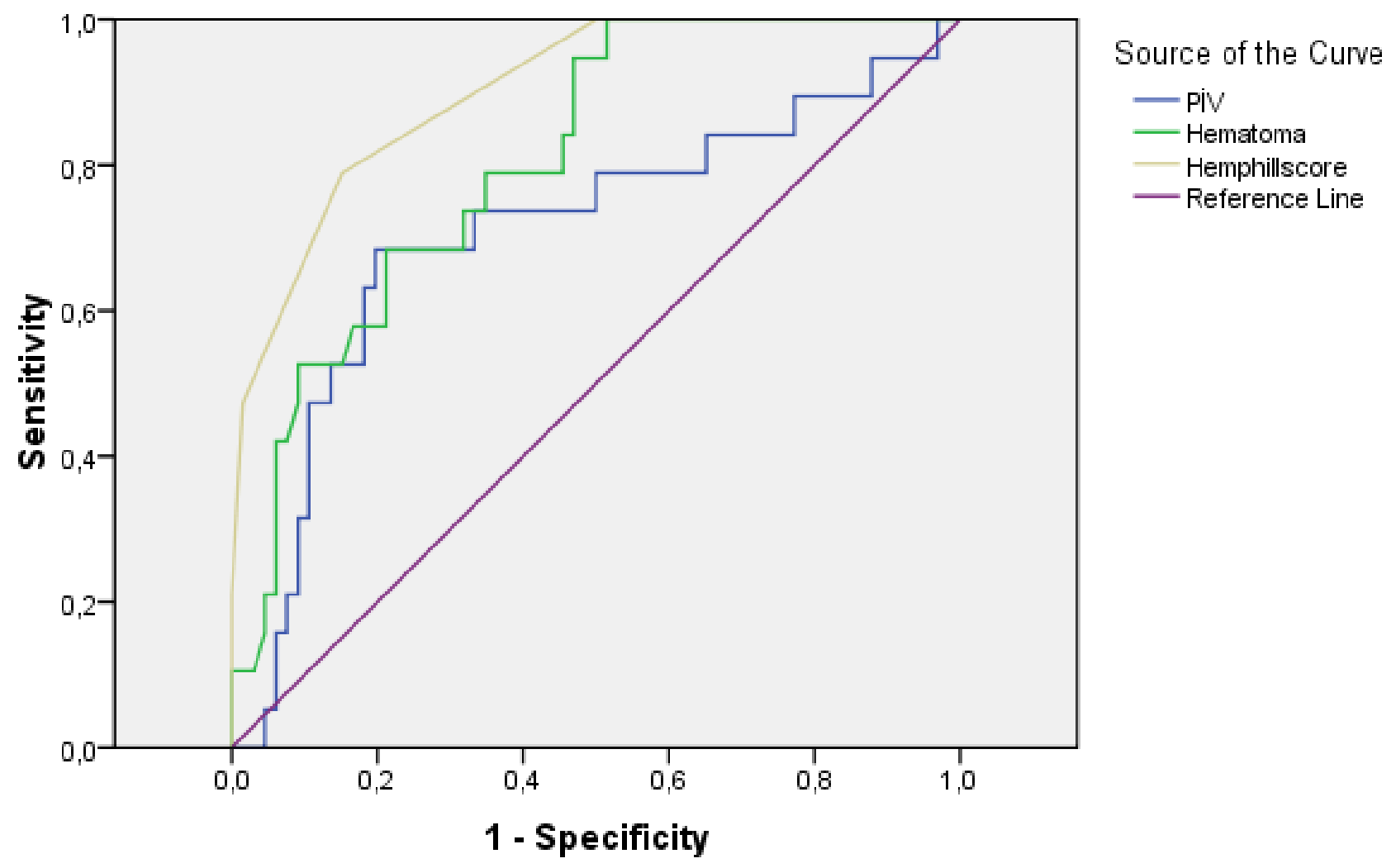

Diagonal segments are produced by ties.

Figure 1. The Roc analysis Platelet volume index, Hematoma and Hemphill score point in predicting mortality in patients with IPC. The AUC, cutoff, of the PVI were $0.708,5.13$, respectively for predicting mortality. The Hemphill Score, AUC, cut-off was $0.9031 .54 \%$, respectively. The ROC analysis results of the Hematoma Size in predicting mortality, AUC, cut-off was $0.80719 .51 \mathrm{cc}$.

\section{Discussion}

Although intraparenchymal hemorrhages are seen at a rate of 10-20\% among all stroke types, their mortality and morbidity are higher than ischemic stroke and subarachnoid hemorrhage $[25,26]$. Early detection of the disease during the diagnosis stage and effective treatment plans may reduce sequelae and mortality rates. The Hemphill Index is used to predict mortality especially in intraparenchymal hemorrhages [5]. In addition to this index, cheap and easily accessible prognostic markers are needed especially starting from $1^{\text {st }}$ line healthcare facilities. In the present study, we evaluated RDW-CV, MPV, and platelet laboratory parameters, which are effective with full blood count, and which are easily available anywhere. The RDW-CV, PIV Index, and Platelet values differed compared to the healthy Control Group.

In the scope of the study, the RDW-CV parameter differed in the patient group compared to the healthy Control Group. The studies in the literature report that the RDW-CV laboratory parameter is increased during inflammation, chronic diseases, and hemorrhage-related diseases [27, 28, 29]. Inflammatory mechanisms are activated because of the damage done to nerve cells in intraparenchymal hemorrhages. In this respect, compensatory hyperplasia of the erythroid cell line is activated. Also, many immature red blood cells are released, and an increase occurs in the RDW-CV parameter [30]. Although they have different mechanisms than our study, some studies conducted on subarachnoid hemorrhage reported an increase in RDW [31,32]. In a study conducted on intensive care patients in the literature, it was reported that RDW might be a marker in predicting mortality [33]. According to our study findings, although we believe that the RDW-CV blood parameters are higher in patients with intraparenchymal hematoma than in healthy patients, it cannot be used as a prognostic marker in mortality evaluation even though we think it may be a marker in intraparenchymal hemorrhages.

The low platelet laboratory parameter levels in the scope of the study compared to the healthy Control Group may be because of the effect of the neuro-inflammatory mechanism and the migration of platelets. A study in the literature supported the results of our study, reporting that low platelet levels are concurrent especially during cerebral hemorrhages [34]. We think that low platelet levels cause clotting disorder, and it might be an element triggering intracerebral hemorrhage. According to the results of our study, it cannot be used as the predictor of mortality, but we think it may be a parameter to be considered in patients with suspected intracerebral hemorrhage. Although platelet levels were found to be low in patients with intracerebral hemorrhage in the study of Arikanoglu et al., which is similar to our study, it was not significant in terms of mortality 
[16]. In a study conducted in the literature, they emphasized that especially the growth in intracerebral hematoma volume was associated with decreased platelet activity and caused a worse prognosis[35].

The Mean Platelet Volume (MPV), which is a laboratory parameter used to evaluate platelet functions, is reported to be a prognostic parameter indicating thromboembolism in ischemic cerebrovascular diseases [36]. In other studies of the literature, increases were reported in MPV levels, especially in thromboembolisms diseases such as Coronary Artery Disease and cerebrovascular disease [37]. The MPV value shows platelet activation. Cytokine, chemokine and clotting factors are activated and released from platelets, which increase in terms of volume in neural inflammation [36]. This occurs because of the increase in MPV values simultaneously with ischemia. Although the MPV value increased in embolism, it was not clear in terms of being a prognostic marker in intracranial hemorrhage. In some previous studies, it was reported that the MPV laboratory parameter remained uncertain in hemorrhagic strokes [38,39]. Although MPV value was low especially in the patient group of our study compared to the healthy Control Group, this difference was not at a statistically significant level. The volume and amount of granulation are definite since the first development of platelets, and although they are a predictive parameter for ischemic cerebrovascular disease, we cannot argue that low MPV levels in hemorrhagic cerebrovascular disease are predictive with these results in our study. In another study conducted on subdural hemorrhages in the literature, it was reported that there were no differences in patients with subdural hemorrhage in MPV value, which is similar to our study [40].

When the PVI results, which was another parameter in our study, were evaluated, Ray et al. reported that PVI value was an important marker in the course of the disease in the study conducted on patients with subarachnoid hemorrhage [41]. Dündar et al. emphasized that the platelet volume and platelet medium changed in response to intra-cranial vasospasm especially in patients with subarachnoid hemorrhage [24]. This occurs especially to limit the neuron damage in the subarachnoid or intra-parenchymal area [42]. As far as we know, studies especially on intraparenchymal hemorrhage and PVI index are limited in the literature. According to the results of our study, significant results were obtained especially in terms of the diagnosis and clinical prognosis evaluation of patients with intraparenchymal hemorrhage. Our study supports the results of previous studies conducted on patients with diseases that proceed with intracranial hemorrhage. In addition, in our study, the value of PVI was associated with the size of the hematoma, which has important sensitivity and specificity in evaluating mortality. As a result, we conclude that PVI Index may be an important marker in early diagnosis and mortality evaluation in patients with intraparenchymal hemorrhage.

According to the results of our study, the Hemphill Index, hematoma size, and PVI Index are important in mortality evaluation. However, MPV, RDW and Platelet are not directly significant in mortality evaluation. However, a correlation was detected between hematoma size and platelet laboratory parameter among blood parameters, and we believe that there may be parameters that may be useful in evaluating mortality.

\section{Limitations}

The biggest limitation of our study was that it was conducted with a limited number of patients. We believe that prognosis will be better evaluated with prospective studies in which more patients and longer-term mortality follow-ups are done.

\section{Conclusion}

Spontaneous Intraparenchymal hemorrhage are among the leading causes of stroke-induced mortality and disability. For this reason, revealing the controllable or not-yet-known risk factors, determining their effects on mortality will give clues regarding the course of treatment and estimation of the prognosis. The Hemphill Score and hemorrhage volume are important factors in mortality evaluation in intraparenchymal hemorrhage. There are not many studied conducted on Platelet Volume Index, and it is an important marker in predicting mortality especially in these patients. Platelet values, on the other hand, affect the volume of hemorrhage; and therefore, we believe that more studies are needed to show that it is a marker in predicting mortality.

Financial support: This study was not funded by any organization.

Conflict of interest: The authors have no conflict of interest in this study.

\begin{tabular}{|c|r|l|}
\hline \multicolumn{2}{|c|}{ Author Contributions } & Author Initials \\
\hline SCD & Study Conception and Design & DA, BB,ES \\
\hline AD & Acquisition of Data & DA,RY,RU \\
\hline AID & Analysis and Interpretation of Data & DA,BC,RY,BB,ES \\
\hline DM & Drafting of Manuscript & DA,BC,RY,BB,RU \\
\hline CR & Critical Revision & DA,BC,RU,ES \\
\hline
\end{tabular}

\section{References}

1. Hankey GJ. Stroke. The Lancet 2017; 389(10069): 641-54. https://doi.org/10.1016/S0140-6736(16)30962-X.

2. Lee WC, Joshi AV, Wang Q, Pashos CL, Christensen MC. Morbidity and mortality among elderly Americans with different stroke subtypes. Cerebrovasc Dis 2007;23(2):221-8. https://doi.org/10.1007/BF02849893.

3. Qureshi AI, Palesch YY, Barsan WG, Hanley DF, Hsu CY, Martin RL, et al. ATACH-2 Trial Investigators and the Neurological Emergency Treatment Trials Network. Intensive blood-pressure lowering in patients with acute cerebral hemorrhage. N Engl J Med 2016;375(11):103343. https://doi.org/10.1056/NEJMoa1603460. 
4. Satopaa, J, Mustanoja S, Meretoja A, Putaala J, Markku Kaste M, Mika Niemela M, et al. Comparison of all 19 published prognostic scores for intracerebral hemorrhage. J Neurol Sci 2017;379: 103-8. https://doi.org/10.1016/j.jns.2017.05.034.

5. Oge DD, Arsava EM, Pektezel MY, Yildiz OK, Topcuoglu MA. Prediction of early prognosis in intracerebral hematomas: Stich-2 prognosis score against hemphill score. Turk J Cerebrovasc Dis 2019; 25(2): 106-12. https://doi.org/10.5505/tbdhd.2019.46320.

6. Suzuki S, Kelley RE, Dandapani BK, Reyes-Iglesias Y, Dietrich WD, Duncan RC. Acute leukocyte and temperature response in hypertensive intracerebral hemorrhage. Stroke 1995;26(6):1020-3. https://doi.org/10.1161/01.STR.26.6.1020.

7. Behrouz R, Hafeez S, Miller CM. Admission leukocytosis in intracerebral hemorrhage: associated factors and prognostic implications. Neurocrit Care 2015;23(3):370-3. https://doi.org/10.1007/s12028-015-0128-7.

8. Aronowski J, Zhao X. Molecular pathophysiology of cerebral hemorrhage: Secondary brain injury. Stroke 2011; 42: (6):1781-6. https://doi.org/10.1161/STROKEAHA.110.596718.

9. Tonelli M, Sacks F, Arnold M, Moye L, Davis B, Pfeffer M. Relation between red blood cell distribution width and cardiovascular event rate in people with coronary disease. Circulation 2008;117(2):163-8. https://doi.org/10.1161/CIRCULATIONAHA.107.727545.

10. Ye Z, Smith C, Kullo IJ. Usefulness of red cell distribution width to predict mortality in patients with peripheral artery disease. Am J Cardiol 2011;107(8):1241-5. https://doi.org/10.1016/j.amjcard.2010.12.023.

11. Ani C, Ovbiagele B. Elevated red blood cell distribution width predicts mortality in persons with known stroke. J Neurol Sci 2009;277(12):103-8. https://doi.org/10.1016/j.jns.2008.10.024.

12. Zorlu A, Bektasoglu G, Guven FMK, Dogan OT, Gucuk E, Ege RM, et al. Usefulness of admission red cell distribution width as a predictor of early mortality in patients with acute pulmonary embolism. Am J Cardiol 2012 ;109(1):128-34. https://doi.org/10.1016/j.amjcard.2011.08.015.

13. Lindemann S, Kramer B, Seizer P, Gawaz M. Platelets, inflammation and atherosclerosis. J Thromb Haemost 2007; 5(Suppl.1): $203-11$. https://doi.org/10.1111/j.1538-7836.2007.02517.x.

14. Tedgui A, Mallat Z. Cytokines in Atherosclerosis: Pathogenic and Regulatory Pathways. Physiol Rev 2006; 86(2): 515-81. https://doi.org/10.1152/physrev.00024.2005.

15. Ziai WC, Torbey MT, Kickler TS, Oh S, Bhardwaj A, Wityk RJ. Platelet count and function in spontaneous intracerebral hemorrhage. J Stroke Cerebrovasc Dis 2003; 12(4): 201-6. https://doi.org/10.1016/S1052-3057(03)00075-2.

16. Arikanoglu A, Cevik MU, Uzar E, Acar A, Akil E, Ekici F, Tasdemir N. The increase of the mean platelet volume in patients with intracerebral haemorrhage. Turk J Neurol 2012; 18:54-6. https://doi.org/10.4274/Tnd.05325.

17. Kothari RU, Brott T, Broderick JP, Barsan WG, Sauerbeck LR, Zuccarello M, Khoury J. The ABCs of measuring intracerebral hemorrhage volumes. Stroke. 1996;27(8):1304-5. https://doi.org/10.1161/01.str.27.8.1304.

18. Yuksel O, Helvaci K, Basar O, Koklu S, Caner S, Helvaci N, Abayli E, Altiparmak E. An overlooked indicator of disease activity in ulcerative colitis: mean platelet volume. Platelets 2009; 20(4): 277-81. https://doi.org/10.1080/09537100902856781.

19. Nadiech AM, Bernstein RA, Levasseur K, Bassin SL, Bendok BR, Batjer HH, et al. Platelet activity and outcome after intracerebral hemorrhage. Ann Neurol 2009;65(3):352-6. https://doi.org/10.1002/ana.21618.

20. Brummitt DR, Barker HF. The determination of a reference range for new platelet parameters produced by the Bayer ADVIA 120 full blood count analyser. Clin Lab Haematol 2000;22(2):103-7. https://doi.org/10.1046/j.1365-2257.2000.00285.x.

21. Zaccardi F, Rocca B, Pitocco D, Tanese L, Rizzi A, Ghirlanda G. Platelet mean volume, distribution width, and count in type 2 diabetes, impaired fasting glucose, and metabolic syndrome: a meta-analysis. Diabetes Me-tab Res Rev 2015;31(4):402-10. https://doi.org/10.1002/dmrr.2625.

22. Kaplan ZS, Jackson SP. The role of platelets in atherothrombosis. Hematology Am Soc Hematol Educ Program 2011;2011:51-61. https://doi.org/10.1182/asheducation-2011.1.51.

23. Hemphill, JC 3rd, Bonovich DC, Besmertis L, Manley GT, Johnston SC. The ICH score: a simple, reliable grading scale for intracerebral hemorrhage. Stroke 2001; 32(4): 891-7. https://doi.org/10.1161/01.STR.32.4.891.

24. Dundar TT, Kitis S, Abdallah A, Yurtsever I, Gulen B. Evaluation of the platelet volume index as a prognostic factor after aneurysmal subarachnoid hemorrhage. J Surg Med 2019;3(9):685-8. https://doi.org/10.28982/josam.567491.

25. Kase CS, Kaplan LR. Intracerebral hemorrhage. Boston: Butterworth-Heinemann. 1994. https://doi.org/10.1016/B978-0-7506-9308-0.50024$\underline{5}$.

26. Cheung RT, Zou LY. Use of the original, modified, or new intracerebral hemorrhage score to predict mortality and morbidity after intracerebral hemorrhage. Stroke 2003;34(7):1717-22. https://doi.org/10.1161/01.STR.0000078657.22835.B9.

27. Fukuta H, Nobuyuki O, Mukai S, Saeki T, Asada K, Wakami K, et al. Elevated plasma levels of B-Type Natriuretic Peptide but Not CReactive Protein are associated with higher red cell distribution width in patients with coronary artery disease. Int Heart J 2009; 50: 301-12. https://doi.org/10.1536/ihj.50.301.

28. Kase CS, Mohr JP, Caplan LR. Intracerebral hemorrhage. In: Mohr JP,Wolf PA, Grotta JC, Moskowitz MA, Mayberg MR, von Kummer R(eds). Stroke Elsevier 2011: 327-6. https://doi.org/10.1016/B0-44-306600-0/50017-1.

29. Paulus EM, Weinberg JA, Magnotti LJ, Sharpe JP, Schroeppel TJ, Fabian TC, Croce MA. Admission red cell distribution width: A novel predictor of massive transfusion after injury. Am Surg 2014;80(7): 685-9. https://doi.org/10.1177/000313481408000724.

30. Kim CH, Park JT, Kim EJ, et al. An increase in red blood cell distribution width from baseline predicts mortality in patients with severe sepsis or septic shock. Critical Care 2013;17(6):R282. https://doi.org/10.1186/cc13145.

31. Chugh C, Nyirjesy SC, Nawalinski KP. Red blood cell distribution width is associated with poor clinical outcome after subarachnoid hemorrhage: a pilot study. Neurocrit Care 2015; 23(2): 217-24. https://doi.org/10.1007/s12028-015-0117-x.

32. Erdogan V, Avci A. Factors affecting mortality in subarachnoid hemorrhage. Med J Bakirkoy 2017;13(4):175-83. https://doi.org/10.5350/BTDMJB201713407. 
33. Oh HJ, Park JT, Kim JK, Yoo DE, Kim SJ, Han SH, et al. Red blood cell distribution width is an independent predictor of mortality in acute kidney injury patients treated with continuous renal replacement therapy. Nephrol Dial Transplant 2012;27(2):589-94. https://doi.org/10.1093/ndt/gfr307.

34. Jennett B, Bond M. Assessment of outcome after severe brain damage. Lancet 1975;1(7905):480-4. https://doi.org/10.1016/S0140$\underline{6736(75) 92830-5}$.

35. Naidech AM, Jovanovic B, Liebling S, Garg RK, Bassin SL, Bendok BR, Bernstein RA, Alberts MJ, Batjer HH. Reduced platelet activity is associated with early clot growth and worse 3-month outcome after intracerebral hemorrhage. Stroke. 2009 Jul;40(7):2398-401. https://doi.org/10.1161/STROKEAHA.109.550939.

36. Kapsoritakis AN, Koukourakis MI, Sfiridaki A, Potamianos SP, Kosmadaki MG, Koutroubakis IE, Kouroumalis EA. Mean platelet volume: a useful marker of inflammatory bowel disease activity. Am J Gastroenterol 2001;96:776-81. https://doi.org/10.1111/j.15720241.2001.03621.x.

37. Greisenegger S, Endler G, Hsieh K, Tentschert S, Mannhalter C, Lalouschek W. Is elevated mean platelet volume associated with a worse outcome in patients with acute ischemic cerebrovascular events? Stroke 2004;35(7):1688-91. https://doi.org/10.1161/01.STR.0000130512.81212.a2.

38. Gonzalez-Duarte A, Garcia-Ramos GS, Valdes-Ferrer SI, Cantu-Brito C. Clinical description of intracranial hemorrhage associated with bleeding disorders. J Stroke Cerebrovasc Dis 2008;17(4):204-7. https://doi.org/10.1016/j.jstrokecerebrovasdis.2008.02.008.

39. Bath P, Algert C, Chapman N, Neal B. Progress Collaborative Group. Association of mean platelet volume with risk of stroke among 3134 individuals with history of cerebrovascular disease. Stroke 2004; 35(3):622-6. https://doi.org/10.1161/01.STR.0000116105.26237.EC.

40. Tuzcu K, Isil Davarci I, Hakimoglu S, Yengil E, Aras M, Sari A, Kekec L, Dikey I. Evaluation of neutrophil/lymphocyte ratio and mean platelet volume in patients with acute and chronic subdural hemorrhage. MKU Med J 2013;4(14):23-30.

41. Ray B, Tinsley L, Ford L, Thompson DM, Sidorov EV, Bohnstedt, BN. Trends of platelet volume index predicts delayed cerebral ischemia after subarachnoid hemorrhage. World Neurosurg 2018;111;e624-e31. https://doi.org/10.1016/j.wneu.2017.12.131.

42. Teo M, Guilfoyle MR, Turner C, Kirkpatrick PJ, Turnel CL, Murray GD, et al. What factors determine treatment outcome in aneurysmal subarachnoid haemorrhage in the modern era? A post-hoc STASH analysis. World Neurosurg 2017;105: 270-81. https://doi.org/10.1016/j.wneu.2017.05.005 